研究論文

\title{
Unpaywall を利用した日本におけるオープンアクセス状況の調査 The State of Open Access in Japan: An Analysis Using Unpaywall
}

\author{
西岡 千文 ${ }^{1 *}$ 佐藤 翔 2 \\ Chifumi NISHIOKA ${ }^{1}$, Sho SATO $^{2}$
}

1 京都大学附属図書館

Kyoto University Library

于 606-8501 京都市左京区吉田本町

E-mail: nishioka.chifumi.2c@kyoto-u.ac.jp

2 同志社大学免許資格課程センター

Center for License and Qualification, Doshisha University

T 302-8580 京都府京都市上京区新町通今出川上ル 同志社大学溪水館 315

E-mail: min2fly@slis.doshisha.ac.jp

* 連絡先著者 Corresponding Author

本稿は Unpaywall を利用して日本と世界のオープンアクセス（OA）状況を調査した。日本の調査では Unpaywall と Scopus に収録されている日本の著者による雑誌論文約 200 万件，世界の調査では Unpaywall に収録されている雑誌論文約 8,000 万件を対象とした。結果，日本と世界の OA の割合はそれぞれ $41.83 \%$, $29.77 \%$ あるることがわかった，日本の割合の高さの要因は，過去に出版された論文の多くがブロンズであ ることである．近年の傾向としてゴールドの割合の上昇が観察された。機関リポジトリで公開されている論 文の割合は 2000 年から 2010 年にかけて増加しているものの，2010 年以降は横ばいで約 $5 \%$ である. 2010 年以降の機関リポジトリのみで $\mathrm{OA}$ である論文の割合は約 $1.5 \%$ である．グリーン $\mathrm{OA}$ を効率よく推進する ためにも，各機関がそれぞれの OA の状況を継続的に把握できるような仕組みが必要である.

This article investigates the state of Open Access (OA) in Japan and the world using a dataset provided by Unpaywall. The analysis covers two million articles for Japan and 80 million articles for the world. We find that the percentages of OA articles in Japan and the world are $41.83 \%$ and $29.77 \%$, respectively. A reason for the high percentage in Japan is that many articles published a long time ago belong to the bronze category. As a trend in recent years, the analysis reveals the percentage of articles in the gold category has increased. Regarding the contribution of institutional repositories (IRs) to OA, we observe the percentage of articles available in IRs increased from 2000 to 2010. However, the percentage has been flat, at $5 \%$, since 2010 . The percentage of articles that are OA only in IRs is $1.5 \%$. To promote green OA efficiently, it is necessary to enable each institution to grasp its state of OA by e.g., developing a system that continuously monitors levels for each institution.

キーワード：オープンアクセス, 学術情報流通, オープンアクセスリポジトリ，機関リポジトリ，学術雑誌 open access, scholarly communication, open access repository, institutional repository, academic journal

\section{1 はじめに}

1990 年代以降, 学術雑誌価格高騰への対応, 研究 成果の迅速かつ自由な共有の実現といった様々な動
機から，オープンアクセス（Open Access，OA）を 推進する取り組みがなされてきた ${ }^{[1]} .2001$ 年に開催 された Budapest Open Access Initiative (BOAI) は, $\mathrm{OA}$ の定義を, 査読つきの学術雑誌論文につい 
て「インターネットにアクセスできることそれ自体 を除く経済的, 法的, 技術的な障壁なく論文を利用 できるようにすること」としている ${ }^{[2,1]}$. BOAI で は OA を実現する手法として, セルフ・アーカイビ

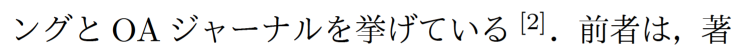
者が Open Archives Initiative（OAI）が定める標 準（OAI-PMH 等）に準拠したオープンな電子アー カイブ (リポジトリ) で論文の電子コピーを公開す ることを指し, グリーン $\mathrm{OA}$ と呼称される. 後者は, 著者が OA ジャーナルに論文を掲載することで OA を実現するもので，ゴールド OA とされている.

2000 年代以降の OA の進展を牽引してきたもの として, 各国, 各機関, 各助成団体で制定されてき た OA 方針が挙げられる ${ }^{[3]} . \mathrm{OA}$ 方針は各国, 各機 関に所属する, あるいは各助成団体から助成を受け ている著者に, 研究成果である論文を $\mathrm{OA}$ で公開す ることを義務付ける。.世界に先駆けて，2005 年に 米国国立衛生研究所は, 助成を受けた論文に対する パブリック・アクセス方針を公開した ${ }^{[4,5]}$. 2010 年 代には，OA を推進する方策は広がりをみせ，OA は実現を疑われる理想から，実現されるであろう具 体的な政策となっている ${ }^{[3]}$. 日本では, 2009 年に 国立大学図書館協会による「オープンアクセスに関 する声明」[6] 以降, OA の推進に関する議論が進ん でいる. 2011 年に公表された第 4 期科学技術基本 計画 ${ }^{[7]}$ では, 研究情報基盤の整備として「OA の 推進」や「機関リポジトリの構築」について言及さ れている. 2015 年には内閣府の国際的動向を踏ま えたオープンサイエンスに関する検討会から報告書 [8] が公表され，以降 $\mathrm{OA} に$ 関する政府提言が数多 く発表されている.

機関単位での OA の推進も行われてきた ${ }^{[9]} .2000$ 年代にはハーバード大学といった欧米の機関で OA 方針の策定が広まった。日本では，2015 年に京都大 学が機関リポジトリを通じた OA を義務化する OA 方針 ${ }^{[10]}$ を策定・公表した. 2019 年 12 月 19 日現在 では，国内 32 機関で $\mathrm{OA}$ 方針が定められている.

このように, これまでに政府や各機関の様々な 方策によって OA が推進されてきた。 今後さらに $\mathrm{OA}$ を推進するための戦略を策定するには, OA の 現沉を把握することが望ましい。これまでに世界の 論文を対象とした OA 状況の調査は行われている $[11,12,13]$ ものの, 日本の論文を対象としたものは 多くはなされていない.日本では機関ごとに OA 方 針の策定·OA の推進が行われてきたことから，機関
ごとの $\mathrm{OA}$ 状況の調査が主に実施されてきたと考え られる. OA を推進するための国全体としての戦略 の検討, 各機関が国内での立ち位置を認識すること を可能とするためにも，本稿では日本全体における $\mathrm{OA}$ 状況の調査を行う. 特に, 日本の $\mathrm{OA}$ 状況を, 世 界のそれと比較して概観する。調査では, Piwowar らの世界の論文を対象とした OA 状況の調査 ${ }^{[11,13]}$ と同様に, データセットとして Unpaywall のデータ ベースのスナップショットを利用した. Unpaywall は Crossref DOI が付与されている各論文の合法的 に OA となっている版を提供するウェブブラウザの プラグインである. 多くの研究者に使用されており， 2020 年 3 月 5 日現在のユーザ数は 204,896 名であ る ${ }^{[14]}$.また, 2019 年 7 月にはプラグインを通じて, 約 300 万件の論文の OA 版のリクエストがあったこ とが報告されている ${ }^{[13]}$. よって, OA となってい る論文の発見可能性という観点からも, Unpaywall を使用した調査には意義があると考える.ゴールド， ハイブリッド，ブロンズ，グリーン，クローズドと いった Unpaywall で与えられている $\mathrm{OA}$ 種別の観 点からの調査とともに, 機関リポジトリ等のリポジ トリによる OA という観点からも調査を行った。

本稿の構成を以下に示す. 次章では, 関連研究と して様々な $\mathrm{OA}$ 種別とこれまでに実施された $\mathrm{OA}$ 状 況の調査を挙げる. 3 章では調査の手法として, 本 稿で使用するデータセットと各論文の $\mathrm{OA}$ 種別を特 定する方法を示す. 4 章では調査の結果を示し, 続く 5 章では結果を考察する．6章を本稿の結びとする.

\section{2 関連研究}

本章では, $\mathrm{OA}$ 状況の調査についての関連研究を 示す. 2.1 節では, これまでの $\mathrm{OA}$ 状況の調査で使 用されてきた様々な $\mathrm{OA}$ 種別について述べる. 続く 2.2 節では，これまでに実施された日本と世界の OA 状況の調査を挙げる.

\section{1 様々な $\mathrm{OA}$ 種別}

BOAI で示されているグリーン OA, ゴールド OA をはじめとして，OA の実現には様々な手段が存在 する.このことから，これまでの $\mathrm{OA}$ 状況の調査で は, 調査ごとに様々な $\mathrm{OA}$ 種別が使用されてきた. Piwowar らの調査 ${ }^{[11]}$ での文献レビューをもとにし て，様々な $\mathrm{OA}$ 種別を下記に示す. 
・ゴールド. OA ジャーナルで出版されている 論文を指す。

・ハイブリッド．購読型雑誌で出版されている が，論文掲載料 (Article Processing Charge, $\mathrm{APC}$ ）の支払いで $\mathrm{OA}$ となった論文を指す.

・グリーン．購読型雑誌で出版されており出版 者では OA となっていないが, 機関リポジト リ，プレプリントサーバ等のリポジトリで $\mathrm{OA}$ となっている論文を指す $[15,16]$.

・ Libre. 読むことができる権利に加えて，ク ローリング，インデキシング，アーカイブ等 のために再利用できる権利が与えられている 論文を指す ${ }^{[17] . ~ B O A I}{ }^{[2]}$ での OA の定義に 近い.

・Gratis. Libreでは再利用できる権利が与え られているのに対して，読むことができる権 利のみが与えられている論文を指す ${ }^{[17]}$.

- 遅延 OA. 購読型雑誌に掲載されており, 一 定期間後に出版者で OA となる論文を指す. Laakso らの調査 ${ }^{[18]}$ によると一定期間後に出 版者で OA となる論文のうち $77.8 \%$ が出版か ら一年以内に OA となっている.

- ASN. ResearchGate ${ }^{[19]} や$ Academia $^{[20]}$ と いった商業のアカデミック・ソーシャル・ネット ワーク（ASN）で公開されている論文を指す。

・ブラック ${ }^{[21]}$. Sci-Hub といった学術論文の海 賊版サイトに公開されている論文を指す。OA 種別としては存在するものの, 違法であること から多くの $\mathrm{OA}$ 状況の調査で対象とはなって いない。これらは Rouge OA や Robin Hood $\mathrm{OA}^{[22,23]}$ とも呼称される.

・ブロンズ. ゴールド, ハイブリッドに該当しな いが，出版者で $\mathrm{OA}$ となっている論文を指す.

・プラチナ/ダイヤモンド $[24,25] . \mathrm{APC}$ が無料 である OA ジャーナルで出版されている論文 を指す，上記のゴールドに含まれている，出 版に要する費用は多くの場合, 学協会によっ て負担されている.

本稿の調査では, Piwowar ら ${ }^{[11]} に$ 倣って, ゴー ルド，ハイブリッド，ブロンズ，グリーンの $\mathrm{OA}$ 種
別を利用する (3.2 節参照) 。この $\mathrm{OA}$ 種別は, 国 外での $\mathrm{OA}$ 状況の調査 ${ }^{[26]}$ 等, 近年最もよく利用さ れている. 遅延 OA については, Piwowar らの最 新の調査 ${ }^{[13]}$ でも扱われているが，本稿では扱わな い. ASN については，一部の OA の調査 ${ }^{[22,27]}$ で は一つの OA の手法として捉えられている. しか し, Jamali ${ }^{[28]}$ によると ResearchGate で公開され ている購読型雑誌の論文のうち約半数が出版者の規 定に反していることが判明している．また，永続的 な公開といった観点から，ASN での OA には䯚念

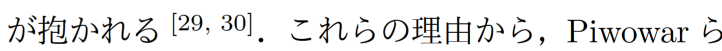
の調査 ${ }^{[11,13]}$ と同様に，本稿では ASN での OA は 扱わない．また，ブラックについては，その手法に 法的な䀣念があることから，本稿では扱わない，近 年 $\mathrm{APC}$ の值上げが進んでいる ${ }^{[31]}$ ことから，プラ チナ/ダイヤモンドは注目すべき $\mathrm{OA}$ 種別であるが, 別稿に袞る.

本稿ではさらに，DOAJへの掲載とライセンスの 付与という観点からゴールドを細分化した分析を実 施する. DOAJ (Directory of Open Access Journals） ${ }^{[32]}$ は，OA ジャーナルを「全コンテンツに無 償でアクセス可能である」かつ「査読・編集によっ て高品質基準を満たしている」学術雑誌と定義して おり,これらの要件を満たす学術雑誌のリストを公 開している. 捕食ジャーナル，ハゲタカジャーナル [33] といった問題が近年注目を集める ${ }^{[34]}$ 中, DOAJ は OA ジャーナルのホワイトリストとして使用され ている．また，BOAIによる OA の定義（1 章参照） $[2,1]$ やSuber による Libre の定義 ${ }^{[17]}$ にもあるよう に，コンテンツの再利用という観点からライセンス を付与することは重要である。これらのことから， DOAJへの揭載とライセンスの付与という観点から の分析を実施する。

また本稿では，リポジトリによる OA に注目した 調査を実施する. Harnad ら $[15,16]$ や Piwowar ら [11]による調査でのグリーンは, 購読型雑誌に掲載 されていてリポジトリで OA となっている論文を指 す.よって,「論文が出版者で OA である」かつ「リ ポジトリでも公開されている」際には, グリーンで あるとは認識されない。さらに，これらのグリーン の定義では機関リポジトリとその他リポジトリを区 別していない．機関りポジトリの「世界に対する大 学の貢献を形作る新しいチャネル」 $[35,36]$ という役 割に注目した際には，OA ジャーナルに掲載されて いる論文が機関リポジトリで OA となっていること 
は意義がある.このことから, 機関リポジトリにお ける OA 状況は大きな関心である。

\section{$2.2 \mathrm{OA}$ 状況の調査}

$\mathrm{OA}$ への関心の高まりから, 数々の $\mathrm{OA}$ 状況の調 査が実施されてきた。本節では, 日本と世界におけ る OA 状況の調査についてそれぞれ述べる.

\subsection{1 日本の OA 状況の調査}

日本の論文全件を対象とした大規模な OA 状況の 調査はなされていないが，関連する調査を下記に挙 げる.

福澤 ${ }^{[37]}$ は, Scopus を利用して, 日本, 米国, ド イッ, フランス, 英国, 中国, 韓国といった主要国 の論文発表の特徵をジャーナルに注目して分析して いる. 研究では, 「OA ジャーナル/それ以外のジャー ナル」という観点からも分析しており，2010２012 年の期間で日本の機関の著者により発表された論文

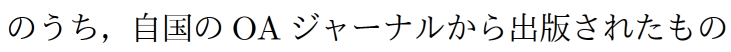
が $4.2 \%$, 他国の OA ジャーナルから出版されたも のが $7.4 \%$ を占めることが明らかになっている.

池内ら ${ }^{[38]}$ は日本の研究者を対象として, 研究 データの公開を中心としたオープンサイエンスの実 態についてのアンケート調査を実施している. 回答 者 1,398 名のうち $70.9 \%$ が OA の論文があると回答 している.

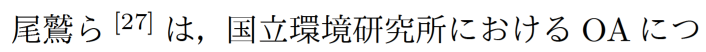
いて,「研究成果のうち $\mathrm{OA}$ になっているものはどの 程度か」を探る OA 度調査と「OA のために必要と なる APC の価格」を探る OA 化調査を実施してい る. 調査では, 所内で運用されている研究成果デー タベースから抽出した 2011〜2016 年度の論文を対 象としている，対象となる各論文について，OA で あるか否か, $\mathrm{OA}$ である際にはさらにゴールドであ るかグリーンであるかというようにその手段にま で言及している.グリーンである場合には, リポジ トリでの OA であるか, ASN での OA であるか, といったプラットフォームの調査も実施している. $\mathrm{ASN}$ での $\mathrm{OA}$ もグリーンとして扱う点は, 本稿と は異なる. 結果として, 2016 年度では 7 割近くの 論文が何かしらの手段で OA となっていることが判 明した.ゴールドの割合が大きく上昇していること が観察された。
国立大学四書館協会オープンアクセス委員会は, 2016〜2017 年にかけて加盟館に対してオープンア クセスへの取り組みに関する実態調査 ${ }^{[39]}$ を実施し た. その中で, コンテンツ種別 (e.g., 学術雑誌論文, 研究費研究成果報告書）ごとに機関リポジトリへの 登録状況を調査している. 結果は大学の規模（学部 数で算出）ごとに示されている. 2014〜2015 年の 学術雑誌論文 (海外) のリポジトリでの捕捉率につ いては, 8 学部以上ある大学では $10 \%$ 程度, $5 \sim 7$ 学 部の大学では $2 \sim 3 \%$ 程度, $2 \sim 4$ 学部の大学では 7 〜 $10 \%$ 程度, 単科大学では $7 \%$ 程度であった。

大学図書館コンソーシアム連合（JUSTICE）は, 日本の著者の論文件数, OA ジャーナルで出版され た論文の割合および APC 支払推定額の調査を実施

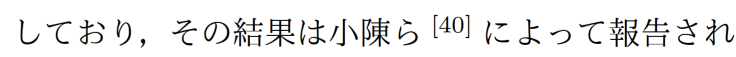
ている. 調査では Web of Science のデータを使用し ており，2012〜2014 年に出版された論文を対象とし ている. 期間中の論文件数は年間約 65,000 件とほぼ 横ばいである. OA ジャーナル掲載論文件数は年々 増加しており, 全論文件数に対する割合は, 2012 年 が $11.6 \%, 2013$ 年が $13.4 \%, 2014$ 年は $14.9 \%$ になっ ている.

Archambault ら ${ }^{[22]}$ の調査（後述）では, 国別の $\mathrm{OA}$ 状況の分析を実施しており, 日本についても触 れられている. 2008〜2013 年に出版された Scopus に收録されている論文を対象としており，日本の論 文の $\mathrm{OA}$ の割合は $44.2 \%$ でり, EU28/ERA の加 盟国平均の $51.3 \%$ や界平均 $47.1 \%$ と比較すると低 い.なお,これらの数值は, 論文の $\mathrm{OA}$ 版を収集す るハーベスト用のエンジンの見落としを考慮して調 整が行われている.

\subsection{2 世界の OA 状況の調査}

世界の論文を対象とした $\mathrm{OA}$ 状況の調査は数多く 実施されている.

Martín-Martín ら ${ }^{[12]}$ は，2009〜2014 年に出版さ れた Web of Scienceに收録されている論文を対象と した OA 状況の調査を Google Scholar を使用して 実施している. 結果, 調查対象の $55 \%$ の論文の OA 版が Google Scholar で見つけられることが判明し た. $23 \%$ が出版者で， $17 \%$ がリポジトリで， $40 \%$ が ResearchGate といったその他のサイトで OA であ ることがわかった. 分野ごとの調査も実施しており, OA の割合が高い分野として自然科学, 医学, 低い 
分野として社会科学, 工学, 人文社会科学を挙げて いる. 地域ごとの調査では, 欧州, アメリカ, ブラ ジルで高い OA の割合（36〜 50\%）であるのに対し て，日本を含めたアジア諸国では $18 ３ 6 \%$ であるこ とを明らかにした。

Archambault らは[22], Scopusに收録されている 1996〜2013 年に出版された論文を対象として，OA 状況の調査を実施している。この調査では, 論文の $\mathrm{OA}$ 種別としてゴールド，グリーン，その他 $\mathrm{OA}$ (ブ ロンズや ASN での OA 等を含む）が採用されてい る. 結果として, 以前と比較してグリーンの伸び率 が小さくなってきていることとゴールドが増加して いることが報告されている．2008２013 年に出版 された論文を対象として, 分野別, 国別の調査も実 施している. OA の割合が高い国として，オランダ, クロアチア, エストニア, ポルトガル, スイス, ブ ラジルが挙げられている。 OA の割合が高い分野と しては, 一般科学・技術, 生物医学, 数学. 統計学, 生物学が挙げられている.

最近の大規模な調査としては, Piwowar らの調査 [11] が挙げられる.この調査は, 尾城らの論考 [41] でも取り上げられている。調査では, Crossref DOI をもつ全ての論文 $66,560,153$ 件のうち 100,000 件, Web of Science に収録されている Crossref DOI を もつ論文 $8,083,613$ 件のうち 100,000 件, 2017 年の とある週に Unpaywall のユーザがアクセスした論 文 213,323 件のうち 100,000 件をサンプルとして使 用している. また, 詳細な $\mathrm{OA}$ 状況の把握のために, 各論文をゴールド，ハイブリッド，ブロンズ，グリー ン，クローズドのいずれかに分類している（2.1 節 参照). Crossref DOI をもつ論文のサンプルについ ては，世界で公開されている論文全件での $\mathrm{OA}$ 状況 を分析するために使用している. 結果， $27.9 \%$ の論 文が OA となっていることが判明した. 内訳として は, ゴールドが $3.2 \%$, 八イブリッドが $3.6 \%$, ブロ ンズが $16.2 \%$, グリーンが $4.8 \%$ であ. さらに, 論 文の出版年別, 出版者別, 分野別の分析も実施して いる. 出版年別の調査では, 出版年が最近であるほ ど, OA の割合が高いことが判明している. Web of Science に収録されている Crossref DOI をもつ論文 のサンプルは, 論文の OA が被引用数に与える影響 を調査するために利用している。結果, グリーン， ハイブリッド，ブロンズであるものについては，平 均よりも多く引用されていることが判明した。対し てゴールドである論文は, 平均やクローズドである
論文よりも被引用数が小さい. Unpaywall のユーザ がアクセスした論文のサンプルは，ユーザが利用す る論文における各 $\mathrm{OA}$ 種別の割合を計算するために 利用されている. 結果として, ユーザがアクセスし た論文のうち $47.0 \%$ OA OA であることが判明した。

Piwowar らは 2019 年にも OA 状況の調査 ${ }^{[13]}$ を 実施している.この調査では, 先行研究 ${ }^{[11]}$ と同様 に, ゴールド，グリーンといった各 $\mathrm{OA}$ 種別の割合 や，Unpaywall のユーザにアクセスされている論文 での OA の割合を分析している.さらに発展させ て, グリーンとブロンズのタイムラグ（OAになる までに要する時間）についても分析を実施している. グリーンについては, プレプリントの登録はごく僅 かであり, 多くの場合に出版から約 1 年後にリポジ トリで公開されていることが判明した。回帰分析に よって将来の予測も実施しており，2025 年の OA の 割合は $44 \%$ でるとしている.

\section{3 手法}

本章は $\mathrm{OA}$ 状況の調査手法について述べる. 3.1 節では利用したデータセットについて， 3.2 節では 各論文の $\mathrm{OA}$ 状況の判断方法について詳述する.

\section{1 データセット}

Piwowar らによる調査 ${ }^{[11,13]}$ と同様, 本稿でも Unpaywall を利用して調査を実施する. Unpaywall が利用するデータベースは公開されており，本稿で は 2019 年 11 月 22 日版を利用した. スナップショット には, Crossref DOI が付与されている 109,905,121 件のレコードのメタデータならびに OA に関する情 報が収録されている，分析では日本と世界の OA 状 況を比較するが，それぞれ下記を調査対象とする。

・日本. Scopus で日本に位置する機関 2,611 件 とそれらの機関の Affiliation ID を取得する. Scopusの Affiliation Retrieval API ${ }^{[42]}$ を利用 して，それぞれの機関の構成員が著者となっ ている DOI が付与された論文を計 3,054,454 件（異なり数）抽出した. それらのうち, Unpaywall のスナップショットに収録されている かつ種別が journal-article（雑誌論文）で ある論文 $2,000,897$ 件を調査対象とする。 
・世界. Unpaywall のスナップショットに収録 されていて, 種別がjournal-article（雑誌 論文）である論文 $79,534,697$ 件を調査対象と する。これには上記の日本の論文も含まれる.

本稿では分野ごとの OA 状況の調査（4.2 節参照） も実施する.しかし Unpaywall は論文の分野に関す るメタデータを収録していない. よって, 本稿では

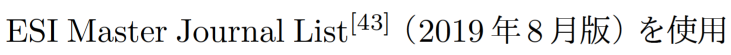
することで，各論文の分野を特定した．ESI Master Journal List は, Essential Science Indicators に収 録されている学術雑誌のリストである.リストには 12,001 件の各学術雑誌のタイトル, ISSN, EISSN, 分野が収録されている. 分野は 22 件存在し, 各学 術雑誌につき 1 件の分野が与えられている. 分野は 論文単位ではなく学術雑誌単位に与えられているも のであるが, 分野ごとの OA 状況を大まかには把握 できると考える. ISSN, EISSN によって紐付けを 行い，論文の分野を特定した。1 件の ISSN に複数 の学術雑誌が紐付けられていることなどを理由とし て, 論文に複数の分野が与えられるケースが発生し た。その際には，1を分野数で割った值を各分野の 重みとする。

\section{2 論文の $\mathrm{OA}$ 種別の特定}

本稿では, 下記の 2 つの観点から OA 状況を調査 する。

- OA の全体像（Unpaywall の OA 種別を利用）

・リポジトリによる OA

本節では，上記の 2 つの観点からの $\mathrm{OA}$ 種別とその 特定方法について詳述する.

\subsubsection{OA の全体像}

Unpaywall の各論文には, フィールド oa_status が存在し, gold, hybrid, bronze, green, closed いずれかの值が与えられている。この $\mathrm{OA}$ 種別は, Piwowar らの調査 ${ }^{[11]}$ で初めて使用され, 現在まで に欧州諸国での OA のモニタリング等, 様々な調査 で利用されている ${ }^{[44,26]}$. これらの $\mathrm{OA}$ 種別の付与 方法は公開されており ${ }^{[45]}$, 表 1 にまとめる. なお, フィールド oa_status が存在しないあるいはフィー ルドが空值である論文が含まれていることが判明し
たため, 本稿では新たに不明という $\mathrm{OA}$ 種別を追加 している.

表 1 にあるとおり, 論文が掲載されている学術雑 誌の種別（OA ジャーナルまたは購読型雑誌）が, OA 種別の決定に大きな役割を果たしている. OA ジャーナルの判定方法についても公開されており [46], 判定方法を図式化したものを図 1 に示す.

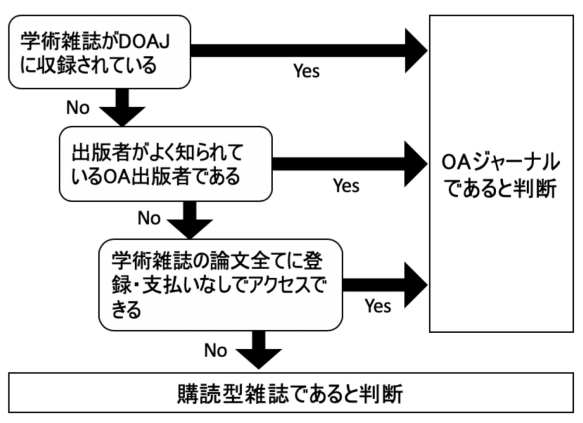

困 1: Unpaywall における OA ジャーナルの判定方 法.

また, Unpaywall では各論文がリポジトリで公開 されているか調査することで，グリーンの判定を 行っている. リポジトリについてであるが, 学術機 関リポジトリデータベース (IRDB) [47]に登録され ている機関リポジトリ 631 件のうち, Unpaywall に 含まれているリポジトリは 76 件である.この数值 は, 2019 年 7 月 10 日時点での IRDB に登録されて いる機関リポジトリの URL のネットワークロケー ションのリストと Unpaywall が日本の論文を公開 していると判断しているリポジトリの URL（3.2.2 項参照）のネットワークロケーションのリストを照 合することによって算出した. 多くの機関リポジト リは主として紀要や学位論文など灰色文献（グレイ

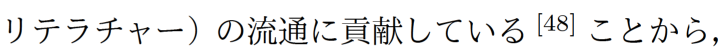
76 件はそこまで小さい值ではないと考える. なお， IRDB には登録されていないが，Unpaywall が日本 の論文を公開していると判断するリポジトリ（海外 のリポジトリ，誤ってリポジトリとして捉えられて いるものも含む）は 2,918 件存在する.

いずれにせよ全ての日本のリポジトリが対象と なっているわけではなく, 結果で示す日本の論文の グリーンの割合は実際よりも低いといえるだろう. 本稿ではリポジトリによる OA に注目した調査も実 施するが (3.2.2 項参照), それらの結果の数值も低 くなるといえる.

また, 本稿ではゴールドの詳細な OA 種別を適宜 
表 1: 「OA の全体像」の調査における $\mathrm{OA}$ 種別

\begin{tabular}{l|l}
\hline \multicolumn{1}{c|}{ OA 種別 } & \multicolumn{1}{c}{ OA 種別が付与される条件 } \\
\hline ゴールド (gold) & OA ジャーナルに揭載されている論文 \\
ハイブリッド (hybrid) & 購読型雑誌に揭載されているが, CC-BY 等のオープンライセンスが付与されている論文 \\
ブロンズ (bronze) & 上記いずれにも該当しないが, 出版者で OA となっている論文 \\
グリーン (green) & 上記いずれにも該当せず, リボジトリのみで OA となっている論文 \\
クローズド (closed) & OA でない論 \\
不明 & フィールド oa_status が存在しない, または空值である論文 \\
\hline
\end{tabular}

利用する。図 1 にあるように,「DOAJ への収録」, 「出版者がよく知られている OA 出版者」, 「学術雑誌 に掲載されている論文全件に無料でアクセス可能」 のいずれかに合致すれば, 学術雑誌は OA ジャー ナルであると判断されている。 2.1 節でも述べたと おり, 近年捕食ジャーナル， 八ゲタカジャーナルと いったといった問題が注目される中, DOAJへの収 録は重要になっている．また BOAI で述べられてい る「できる限り制限のない利用条件」を実現するた めには，ライセンスを明記することが重要である. これらのことから，ゴールドを下記のとおり 4 つの OA 種別に分類して詳細な調査を実施する。なお， 本稿では「DOAJ 掲載論文」は「DOAJに収録さ れている OA ジャーナルに掲載されている論文」を 指す.

- DOAJ 掲載論文・ライセンス付

・ DOAJ 掲載論文・ライセンスなし

・その他 OA ジャーナル掲載論文・ライセンス付

・その他 $\mathrm{OA}$ ジャーナル掲載論文・ライセンス なし

\subsection{2 リポジトリによる OA}

表 1 にあるように, Unpaywall の OA 種別での グリーンは「リポジトリのみで OA となっている論 文」を指す。よって, 出版者で OA となっている論 文は,リポジトリで公開されていたとしても考慮さ れない.しかし機関リポジトリの「世界に対する大 学の貢献を形作る新しいチャネル」[35, 36] や「機関 の研究成果やその他の学術および教育リソースを発 信」 [49] という役割に注目すると, 出版者で OA と なっている論文も機関リポジトリに収録されること が望ましい，さらに，著者の OA に対する意識を把 握するためにも，プレプリントサーバ等その他のリ
ポジトリでの OA についても調査することが求めら れる.これらのことから本稿では, リポジトリによ るOAに注目した調査を実施する.

表 2 にこの調査で利用する OA 種別とその付与方 法を記す. Unpaywall の各論文には oa_locations というフィールドが存在しており，論文が OA であ る際には 1 件以上のオブジェクトが格納されている. 各オブジェクトには, OA となっているサイトについ ての情報が格納されている. 具体的にはhost_type, url といったフィールドが存在しており,「出版者で の OA またはリポジトリでの OA であるか」といっ た情報や「その論文の OA 版の URL」が格納され ている ${ }^{[50]}$ 。これらの情報を利用して，OA 種別を 付与する.

なお，表 2 の 2 行目以下の $\mathrm{OA}$ 種別については, 日本の論文のみを調査対象とする。また，この $\mathrm{OA}$ 種別における「機関リポジトリ」は「日本の機関リ ポジトリ」を指し, 海外の機関リポジトリはその他 リポジトリとして認識される。表 2 の $2 \cdot 3$ 行目に ある URL のネットワークロケーションは, Python のモジュール urllib.parse ${ }^{[51]}$ を使用して特定す る. 調査では, ネットワークロケーションが.jpで 終わるリポジトリを機関リポジトリとする，日本の 論文を多く公開しているネットワークロケーション が.jp で終わるリポジトリ上位 30 件を調査したと ころ，30 件中 29 件が機関リポジトリであった。ネッ トワークロケーションが.jp で終わるリポジトリは 448 件見つかり計 53,441 件の日本の論文を公開し ている．そのうち上位 30 件のリポジトリで公開さ れている論文は計 49,392 件であり，全体の $92.42 \%$ を占めている.よって，この調査で報告される機関 リポジトリによるOA の割合は，実際よりも低いこ とはあっても, 高いことはないといえるだろう. 
表 2:「リポジトリによる OA」の調査における $\mathrm{OA}$ 種別.

\begin{tabular}{|c|c|}
\hline $\mathrm{OA}$ 種別 & $\mathrm{OA}$ 種別が付与される条件 \\
\hline リポジトリで OA である論文 & $\begin{array}{l}\text { フィールド oa_locations に, host_type が repository であるオブ } \\
\text { ジェクトが } 1 \text { 件以上格納されている論文 }\end{array}$ \\
\hline 機関リポジトリで OA である論文 & 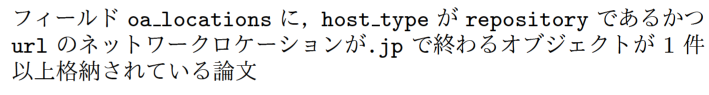 \\
\hline 機関リポジトリ以外のリポジトリで OA である論文 & 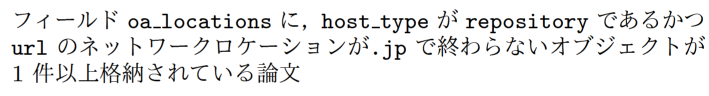 \\
\hline 機関リポジトリとその他リポジトリで OA である論文 & $\begin{array}{l}\text { 上記の「機関リポジトリで OA である論文」「機関リポジトリ以外の } \\
\text { リポジトリで OA である論文」両方に該当する論文 }\end{array}$ \\
\hline 機関リポジトリでのみ OA である論文（出版者でも OA ではない論文） & 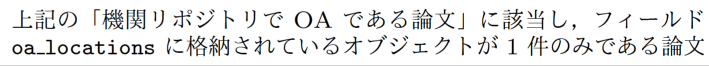 \\
\hline
\end{tabular}

\section{4 結果}

本章では, 日本における OA 状況の調査結果を示 す. 4.1 節では, 日本と世界の論文における OA 状 況について述べる. 続いて, 分野 (4.2 節), 出版 年（4.3節）といった観点から, OA 状況を報告す る. 4.4 節では論文の公開に利用されているリポジ トリについて述べる.

4.1 節， 4.2 節， 4.3 節では 3.2 節で示した OA の 全体像とリポジトリによる $\mathrm{OA}$ という 2 つの観点か らの分析結果を別々に示す.

なお，本章では結果の多くを図で表しているが， 四のもととなったデータについては付録に示す（本 稿の電子版参照) .

\section{1 全体}

\subsubsection{OA の全体像}

日本と世界の OA 状況を表 3 に示す. OA である論 文の割合は，日本と世界それぞれで $41.83 \%, 29.77 \%$ であることから，日本のほうが高い，理由としては， 日本のブロンズの割合の高さが挙げられる. その他 の $\mathrm{OA}$ 種別の割合については, 日本と世界で大きな 差は存在しない.

また, 3.2.1 項で示したとおり, DOAJ への掲載 とライセンスの付与という観点から，ゴールドを 4 つの $\mathrm{OA}$ 種別に分類した結果も表 3 に示す.ここで も日本と世界で大きな差は観察されない. ゴールド の中では, 「DOAJ 掲載論文・ライセンス付」と「そ の他 OA ジャーナル掲載論文・ライセンスなし」に 分類されるものが多数を占める. DOAJ の収録要件 としてライセンスの明示が挙げられている ${ }^{[52]}$.こ
の要件が論文を DOAJ 掲載論文とその他 OA ジャー ナル掲載論文に分割しているといえる.

なお本稿では, 日本の機関の構成員が少なくとも 一名以上著者となっていて, かつ Scopusに収録さ れている論文を日本の論文としている．Scopusに 收録されるには，查読体制，被引用数等の基準 $[53]$ を満たした学術雑誌に揭載されなければならない。 よってここでの日本の論文には，ハゲタカジャーナ ル掲載論文は含まれていない可能性が高い。一方, 世界の論文については, Crossref DOI が付与され ている論文全てが対象となっているので, 八ゲタカ ジャーナル掲載論文が含まれているだろう.

表 3: 日本と世界の $\mathrm{OA}$ 状況.

\begin{tabular}{|c|c|c|}
\hline OA 種別 & 日本（\%） & 世界（\%） \\
\hline $\mathrm{OA}$ & 41.83 & 29.77 \\
\hline ゴールド & 7.33 & 7.67 \\
\hline DOAJ 掲載論文・ライセンス付 & 5.02 & 5.22 \\
\hline $\begin{array}{l}\text { DOAJ 掲載論文・ライセンスな } \\
\text { し }\end{array}$ & 0.34 & 0.66 \\
\hline $\begin{array}{l}\text { その他 OA ジャーナル掲載論文· } \\
\text { ライセンス付 }\end{array}$ & 0.29 & 0.71 \\
\hline $\begin{array}{l}\text { その他 OA ジャーナル掲載論文· } \\
\text { ライセンスなし }\end{array}$ & 1.68 & 1.09 \\
\hline ハイブリッド & 3.09 & 3.37 \\
\hline ブロンズ & 24.37 & 10.45 \\
\hline グリーン & 7.04 & 8.28 \\
\hline クローズド & 58.16 & 70.08 \\
\hline 不明 & 0.01 & 0.15 \\
\hline
\end{tabular}

\subsection{2 リポジトリによる OA}

続いて，3.2.2 項で示した手法を用いて，日本と 世界のリポジトリによる OA 状況を調査した。結果 
を表 4 の 1 行目に示す. 表 3 では世界のグリーンの 割合のほうが僅かに高かったが，リポジトリで OA である論文の割合は日本のほうが高い。このことか ら，日本のほうが出版者で OA となっている論文を リポジトリによく登録しているといえる.リポジト リの種別などに注目した分析の結果を, 表 4 の 2 行 目以下に示す. 圧倒的に多くの論文が，機関リポジ トリ以外のリポジトリで公開されていることがわか る. なお表 4 の 1〜 4行目は, 出版者で OA となっ ている論文も含む. 表 4 の 5 行目に示す機関リポジ トリのみで OA である論文は, $0.83 \%$ とごく僅かで ある。

\section{2 分野}

異なる学術分野では出版についても様々な慣習を もっており, OA 状況には大きな差異があることが 想定される.このことから，分野ごとに OA 状況を 探る．各論文の分野は，3.1節で述べたとおり，ESI Master Journal List を使用して特定した。

\subsubsection{OA の全体像}

図 2 と図 3 に, 日本と世界における分野ごとの OA 状況を示す. 図の右端にある数值は各分野の論 文件数である.

ほとんどの分野において, 日本の各 OA 種別の割 合は, 世界の割合よりも高い. 物理学, 生物学・生 化学, 神経科学・行動科学, 微生物学, 環境学・生 態学の分野においては, 世界の割合のほうが高い. 神経科学・行動科学については, 差が $6.73 \%$ 存在す る. 日本における当該分野でのブロンズとグリーン の割合の小ささが原因である. 生物学・生化学では 差が $5.09 \%$ 存在しており, 日本における当該分野で のハイブリッドとグリーンの割合の小ささが原因と なっている．物理学では差が $4.70 \%$ 存在しており, 日本における当該分野でのグリーンの割合の小ささ が理由である．その他分野では差はいずれも $2 \%$ 未 満であった。

OA の割合が高い分野としては, 学際的領域と宇 宙科学が挙げられる.いずれも $80 \%$ 以上という高い 割合である. なお, 3.1 節で述べたとおり, 分野は学 術雑誌単位で与えられるものである.よって学際的 領域は「論文が学際的な研究を扱っている」という わけではなく, むしろ「論文が掲載されている学術
雑誌が様々な分野を対象としていて学際的である」 というほうが近い. 学際的領域についてはゴールド, 宇宙科学についてはブロンズとグリーンによって， OA の割合が高くなっている. 日本ほど高い数值では ないものの, 世界における学際的領域と宇宙科学で も同様の傾向が観察される. 学際的領域については, メガジャーナル ${ }^{[54]}$ の影響を受けている. 日本におい ては学際的領域の論文が 44,571 件（図 2 参照）存在 するが，そのうち 12,613 件が PLOS ONE（実際の 集計では 6,351 件が PLoS ONE，6,262 件が PLOS ONEであったが，同一の学術雑誌であるので合算), 9,428 件が Scientific Reportsに掲載されているも のである. 宇宙科学については主要な学術雑誌であ る The Astrophysical Journal, Publications of the Astronomical Society of Japan, Monthly Notices of the Royal Astronomical Society に掲載されてい る論文の多くがブロンズであることによって，ブロ ンズの割合が高くなっている.

続いて図 2 と図 3 からゴールドを分野ごとに抽 出し, DOAJへの掲載とライセンスの付与という 2 つの観点からの詳細なゴールドの OA 状況を調査し た。結果を図 4 （日本）と図5（世界）に示す。ほ とんどの分野で,「DOAJ 掲載論文・ライセンス付」 が高い割合を占めていることがわかる．例外として は, 日本における薬理学・毒性学と農学が挙げられ, 「その他 $\mathrm{OA}$ ジャーナル掲載論文・ライセンスなし」 が半数以上を占めている.

\subsection{2 リポジトリによる OA}

リポジトリによるOAの全体像を探るために，各 分野ごとにリポジトリでの公開状況を探る. プレプ リントサーバである arXiv をはじめとして, SSRN, bioRxiv と様々なリポジトリが分野ごとに発展して きた。このことから，分野ごとに異なる結果が観察 されることが期待される.

図 6 に, 日本と世界でのリポジトリで公開され ている論文の割合を分野ごとに示す. 日本において は, 学際的領域と宇宙科学で高い割合が示されてい る.図 2 にあるとおり学際的領域ではメガジャーナ ルの影響からゴールドが多数を占めており，相対的 にはグリーンの割合は高くない.このことは, 学際 的領域でゴールドである論文の多くが，リポジトリ にも登録されていることを示す，世界においては， 学際的領域, 微生物学, 宇宙科学がいずれも 4 割程 
表 4: 日本と世界のリポジトリによる OA 状況.

\begin{tabular}{l|r|r}
\hline \multicolumn{1}{c|}{$\mathrm{OA}$ 種別 } & 日本 $(\%)$ & 世界 (\%) \\
\hline リポジトリで OA である論文 & 19.90 & 17.57 \\
\hline 機関リポジトリで OA である論文 & 2.36 & - \\
機関リポジトリ以外のリポジリで OA である論文 & 18.71 & - \\
機関リポジトリとその他リポジトリで OA である論文 & 1.17 & - \\
機関リポジトリでのみ OA である論文 (出版者でも OA ではない論文) & 0.83 & - \\
\hline
\end{tabular}

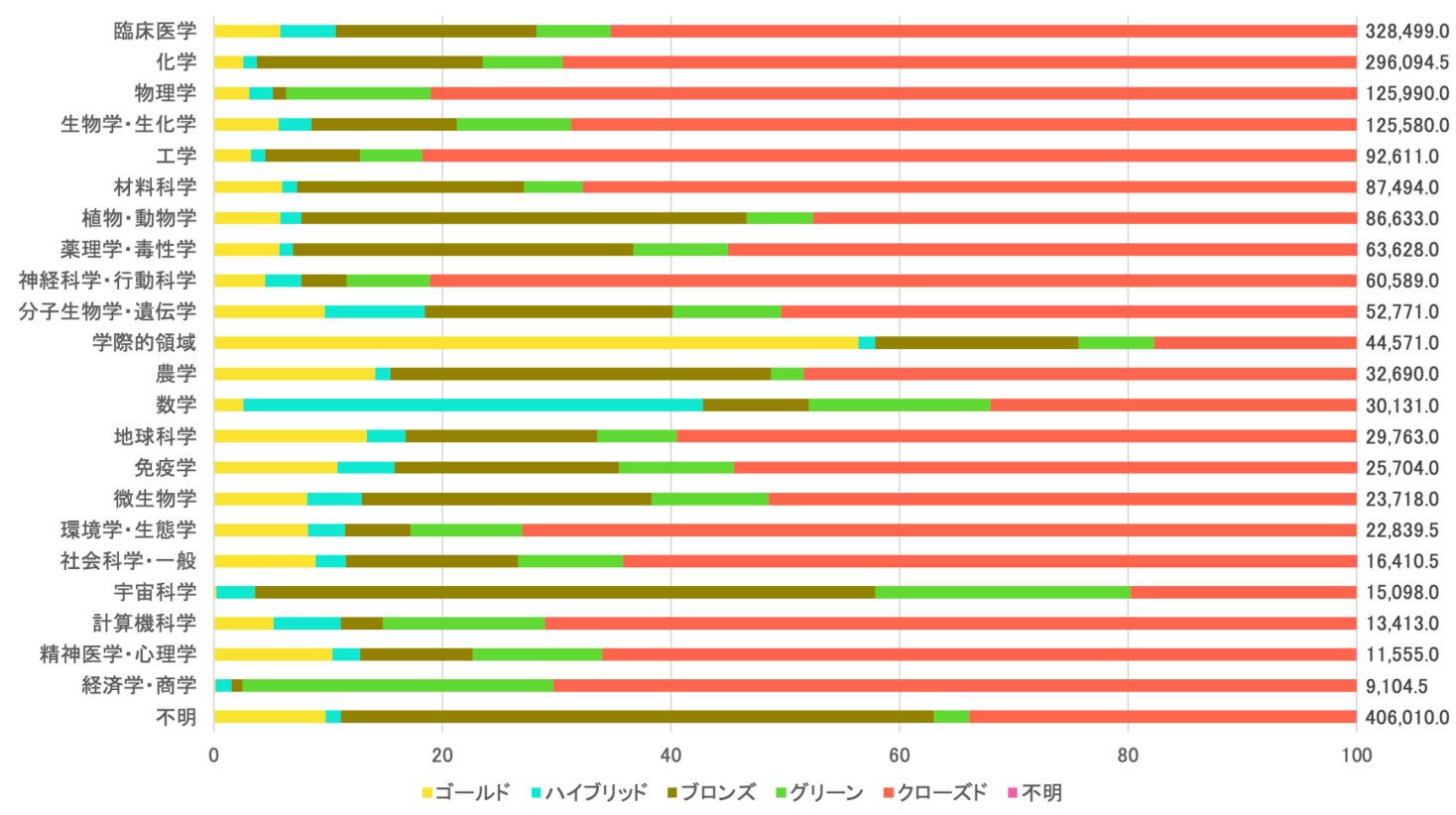

図 2: 日本における分野ごとの $\mathrm{OA}$ 状況.

度であり，他の分野よりも高い数值を示している。 グリーンが進んでいない分野としては, 日本と世界 共通して, 化学, 工学, 材料科学が挙げられ, いず れも 1 割程度である.

リポジトリの種別などに注目したより詳細な結 果を, 図 7 に示す. 図 6 より学際的領域と宇宙科 学の論文が多くリポジトリで公開されていること が判明したが，その多くは機関リポジトリ以外のリ ポジトリで OA となっていることがわかった．特に 学際的領域はメガジャーナルの影響を受けており, それらの多くがライセンスを明記していることか ら, Semantic ScholarやPubMed Central といった 様々なサービスで公開されている. なお, Semantic Scholar や PubMed Central をリポジトリとして捉 えることには議論があると思われる（4.4 節参照） が, Unpaywall ではリポジトリの一つとして捉えら れているため, そのままの結果を示している．機関
リポジトリでの公開が進んでいる分野として, 学際 的領域と経済学・商学が挙げられる. 学際的領域に ついては, メガジャーナルの論文を中心にライセン スが付与されたゴールドの論文が多いことから，機 関リポジトリへの登録が進展していることが理由と して考えられる．経済学・商学については，機関リ ポジトリで公開されている論文が特定の学術雑誌に 偏っているということは観察されなかった.

機関リポジトリでの公開が進んでいない分野とし て, 不明, 農学, 薬理学・毒性学が挙げられる. 理由 の一つとして，これらの分野ではゴールドでもライ センスが付与されていない論文が多く（図 4 参照）, 機関リポジトリでの公開が進みにくいことが挙げら れる. 


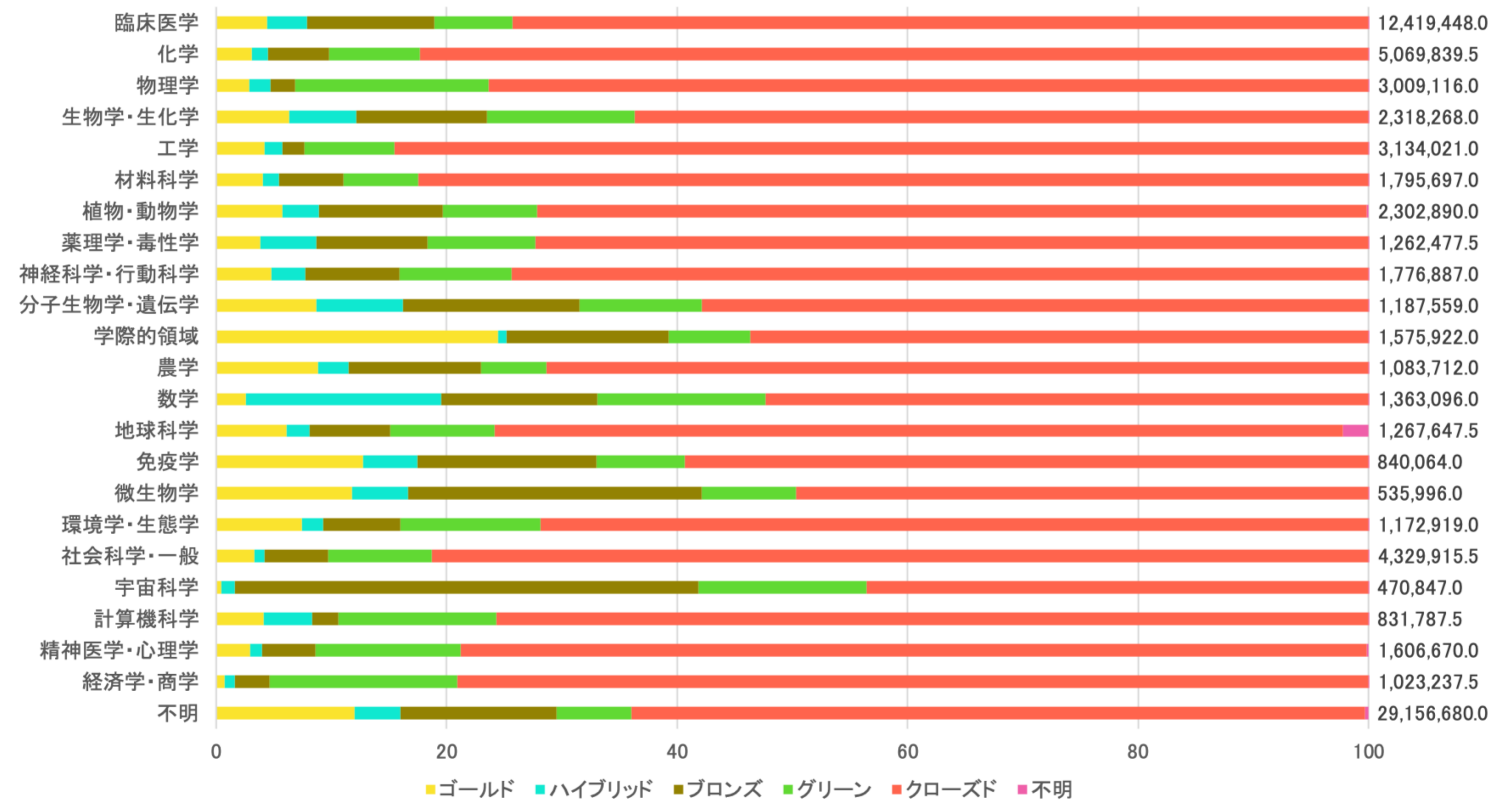

図 3: 世界における分野ごとの $\mathrm{OA}$ 状況.

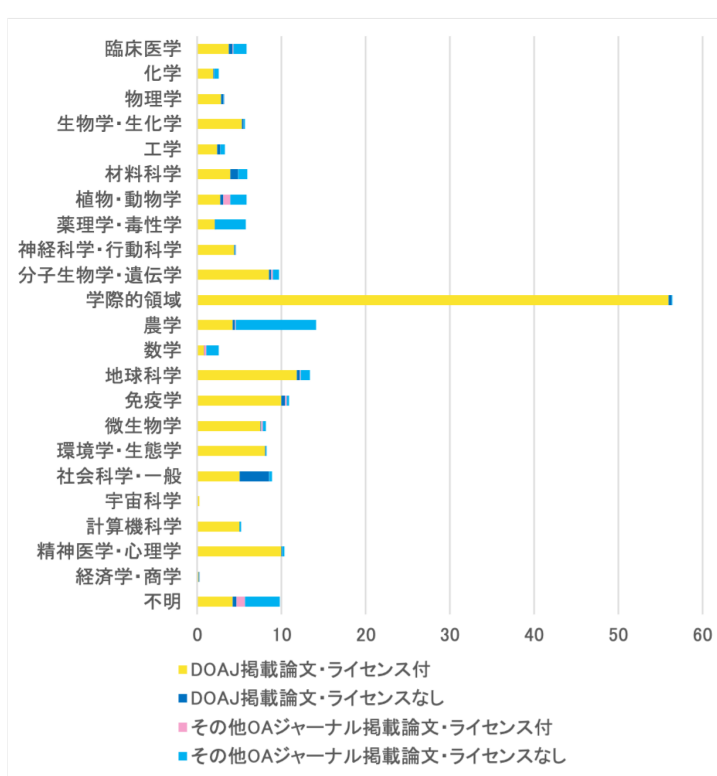

図 4: 日本における分野ごとのゴールド OA の状況.

\section{3 出版年}

過去 30 年間で学術情報流通は大きく変化した. 近年では, $\mathrm{OA}$ の需要・認知が高まり, 様々な $\mathrm{OA}$ ジャーナルが嬹隆している. また, 出版者によって は論文の OA を一定期間禁止するエンバーゴ期間 を設けている.このことから, 論文の $\mathrm{OA}$ 状況は

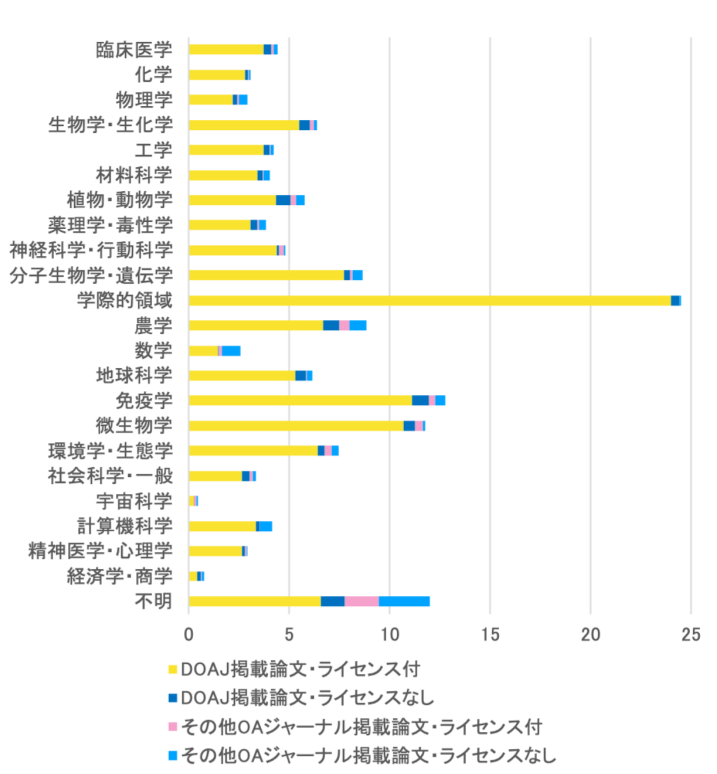

図 5: 世界における分野ごとのゴールド OA の状況.

出版年によって大きく変化すると考えられる．本節 では，論文の出版年別に OA 状況を調査する．各 論文の出版年は Unpaywall に登録されているメタ データより取得した。対象とする出版年は 1990〜 2018 年であり，この期間に出版された日本の論文 は $1,782,243$ 件（日本の論文全件の $89.07 \%$ ），世界 の論文は $61,949,966$ 件（世界の論文全件の $77.89 \%$ ） 


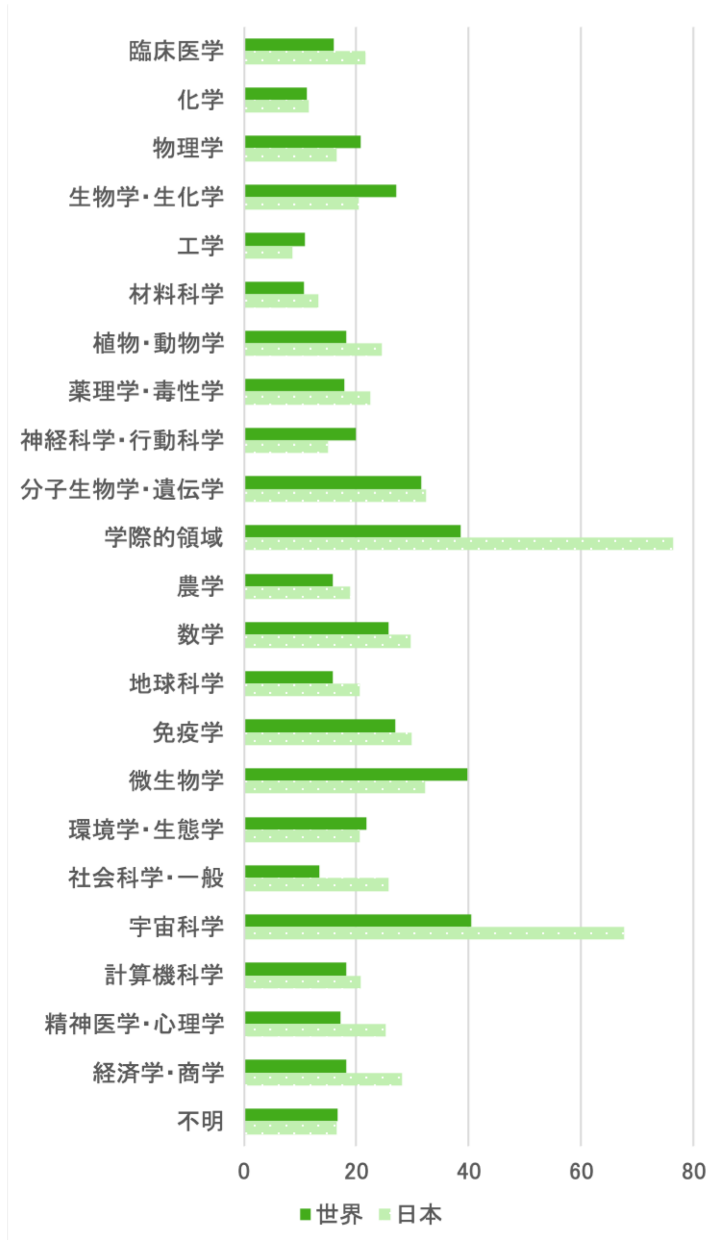

図 6: 分野ごとのリポジトリによる $\mathrm{OA}$ 状況.

である，以下では，OA の全体像とリポジトリによ る $\mathrm{OA}$ という異なる 2 つ観点から結果を述べる.

\subsubsection{OA の全体像}

図 8 と図 9 に, 日本と世界における出版年ごと の各 OA 種別の割合（数值は左軸に対応）と全論 文件数（数值は右軸に対応）を示す. 日本では, 直 近の 10 年間に出版された論文に注目すると, 概ね 40\%の論文が OA になっていることがわかる. Archambault ら ${ }^{[22]}$ は 2008〜2013 年を対象とした調 査で日本の OA の割合を $44.2 \%$ と報告しているが, その結果とも概ね一致する。 なお, Archambaultら [22] は ResearchGate ${ }^{[19]}$ 等の ASN (Academic Social Network）での OA もカウントしていることか ら, 彼らが算出した OA の割合のほうが若干高い. Web of Science を利用して調查を行なった小陳ら

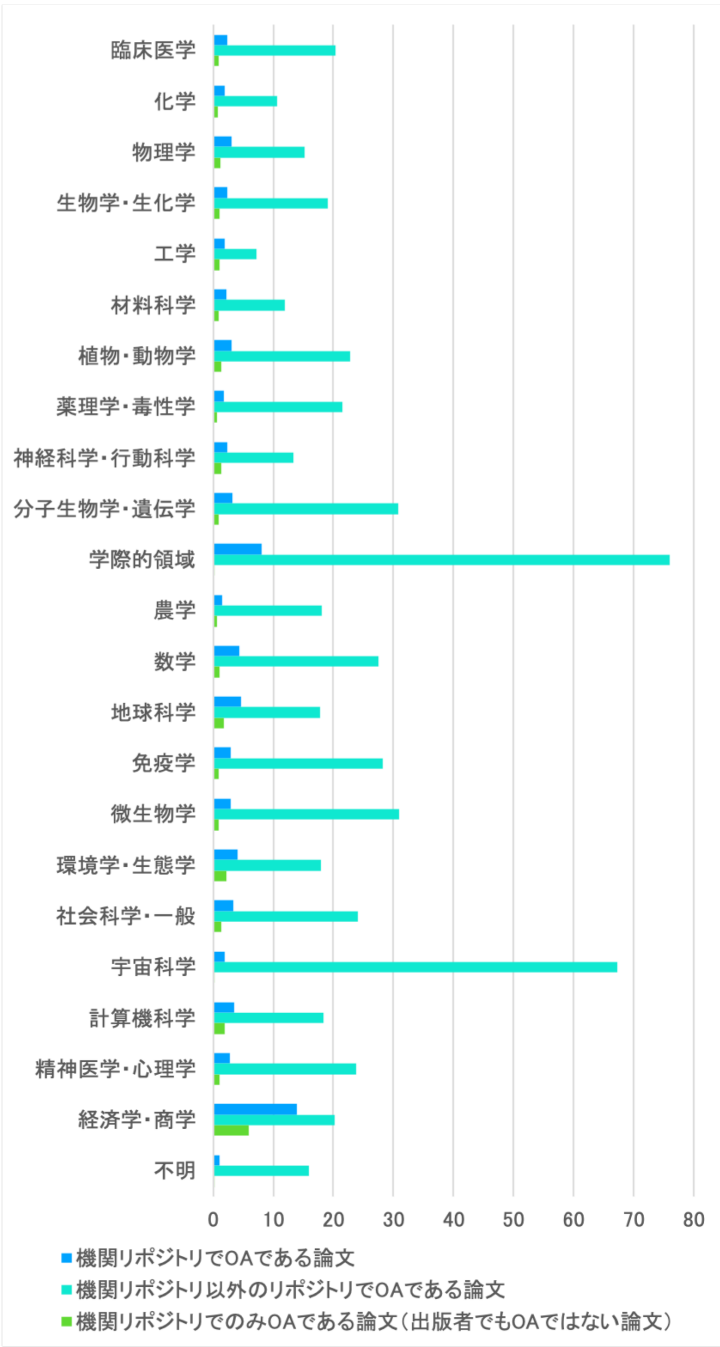

図 7: 日本における分野ごとのリポジトリによる OA 状況.

[40] は, 2012〜2014 年に出版された論文件数はいず れの年も 65,000 件程度であったと報告している. 本 稿で使用した Scopus は Web of Science よりも収録 範囲が広いため, 1 割程度論文件数が多い.内訳に 注目すると, 特にゴールドの割合が近年顕著に伸 びている. 小陳ら ${ }^{[40]}$ は, OA ジャーナル掲載論文 件数（i.e., ゴールド）の割合を 2012 年が $11.6 \%$, 2013 年が $13.4 \%, 2014$ 年が $14.9 \%$ であると報告し ている. 図 8 では 2012〜2014 年にかけて, 8.98\%, $11.41 \%, 15.12 \%$ と変化しており，概ね同様の傾向 である.ゴールドに対して，ブロンズの割合は減少 している，世界と比較すると，過去の論文でのブロ ンズの割合が圧倒的に高いことがわかる.4.1節で は日本における OA の割合の高さの要因として「ブ 
ロンズの割合の高さ」を挙げたが，これらは過去の 論文に起因するものであることがわかる.

また，日本の論文件数に注目すると，2004 年か ら 2005 年にかけて急激に上昇している。この原因 としては，2002 年 9 月に JST リンクセンター [55] が設立されて Crossref のサービスに参加したこと [56]によって，J-STAGEで公開されている論文を中 心に Crossref DOI の付与が進んだことが原因だと 思われる. 図 10 にDOI が付与されていない論文も 含めた Scopus での日本の論文件数の推移を示すが, 図 8 の論文件数の推移と比較すると, 2004 年から 2005 年にかけての上昇幅が小さい.

ゴールドを細分化した詳細な結果については, 出 版年による内訳の変化が少ないことから省略する.

\subsection{2 リポジトリによる OA}

図11に，日本と世界でのリポジトリで OA となっ ている論文の割合を出版年ごとに示す，日本と世界 は概ね同様の傾向であるが，近年では日本のほう が若干高い. 図 12 に日本の論文のみを対象として, リポジトリの種別などに注目したより詳細な結果を 表す、機関リポジトリとその他リポジトリでは，い ずれの出版年でもその他リポジトリで公開されて いる論文の割合が圧倒的に高い。これらのリポジト リとしては, Semantic Scholar, PubMed Central, Europe PMC, arXiv が挙げられる (4.4 節参照). 特に, 2012〜2016 年にかけてその他リポジトリで公 開されている論文の割合は増加している. 図8では 当該期間にグリーンの割合は増加しておらず，ゴー ルドの割合が顕著に伸びている. ゴールドで出版さ れた論文の多くには CC-BY 等のライセンスが付与 されていることから，その他リポジトリでこれらの 論文の公開が進んだと考えられる. 機関リポジトリ で公開されている論文の割合は，2010 年以降は $5 \%$ 程度である. また，機関リポジトリのみで公開され ている論文の割合は $1 \sim 2 \%$ 程度である.この割合は 近年は隇少傾向にあり, 理由の一つとして出版者の 定めるエンバーゴ期間が挙げられる。また， OA に 対する意識が高い著者が $\mathrm{OA}$ ジャーナルでの出版を 選択することで，相対的に機関リポジトリのみで公 開される論文が減少してしまうことも一因かもしれ ない. 図 8 では, 近年はゴールドの割合が上昇して いることがわかる.

\subsection{OA に使用されているリポジトリ}

リポジトリによる OAについて詳しく探るため, 論文が公開されているリポジトリの調査を実施した。 3.2 .2 項で述べたとおり, Unpaywall の各論文には, OA である場合，oa_locations というフィールドが 存在する. oa_locations の值はリストであり,リス トの各オブジェクトには OA となっているサイトに ついての情報が格納されている. その中でもフィール ド host_typeには publisher または repository という值が割り当てられており,「そのサイトが出版 者であるかリポジトリであるか」ということがわか る. 調査では各論文のフィールド oa_locations か らオブジェクトのタイプが repository であるもの を抽出し，url のネットワークロケーションとその 頻度を集計した.

日本の論文を対象とした結果を表 5 に示す. 公開 している論文件数が最も高いリポジトリはSemantic Scholar である. Semantic Scholar は計算機科学分 野と生物医学分野の論文の検索プラットフォームで ある。一般的には著者自身でリポジトリに登録す ることができず，あらゆるリポジトリから論文の PDF ファイルを収集して公開するアグリゲータと して捉えられる. 2 位と 3 位は, PubMed Central と Europe PMCである. PubMed Central や Europe PMC は著者がアップロードすることも可能である $[57,58]$ が，多くの場合は出版者等から PDF を取得 して公開している．著者のアップロードによる公開 がメインとなっている機関リポジトリ以外のリポ ジトリとしては, arXiv (4 位), figshare (7 位), CERN Document Server（8 位）が挙げられる. 機 関リポジトリとしては, 京都大学 $(5$ 位), 北海道 大学 $(6$ 位), 筑波大学 $(9$ 位), 金沢大学 (10 位) のものが上位 10 件に含まれている. 以上のことか ら，機関リポジトリを除いて日本の論文の公開に利 用されているリポジトリとしては, arXiv, figshare, CERN Document Server が利用頻度が高いといえ る.なお，海外の共著者が論文をリポジトリに登録 している可能性もあるため, 日本の著者による OA で利用されているリポジトリであるとは必ずしもい えない.

さらに，世界の論文を対象とした結果を表 6 に示 す. 1〜4位は表 5 の日本の結果と同様である. 5 位は OpenAIRE と CERNによって開発された Zenodo である. データセットを含めた様々な成果を共有で 


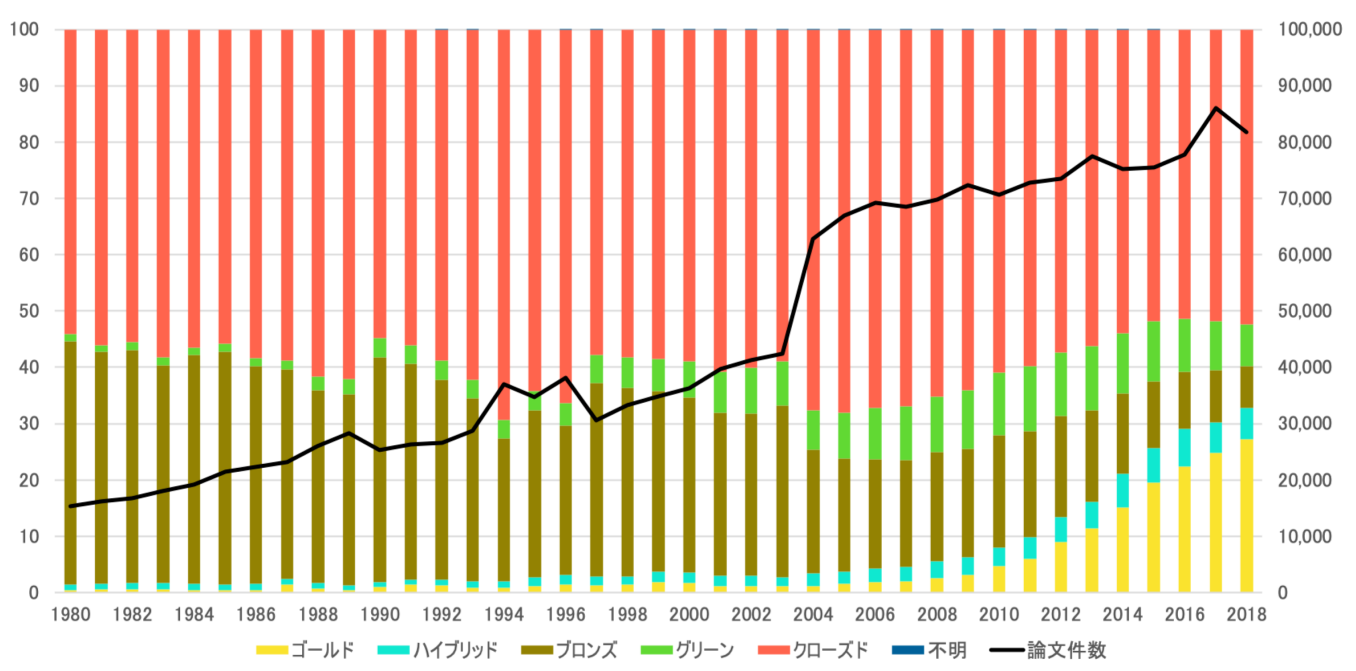

図 8: 日本における出版年ごとの $\mathrm{OA}$ 状況.

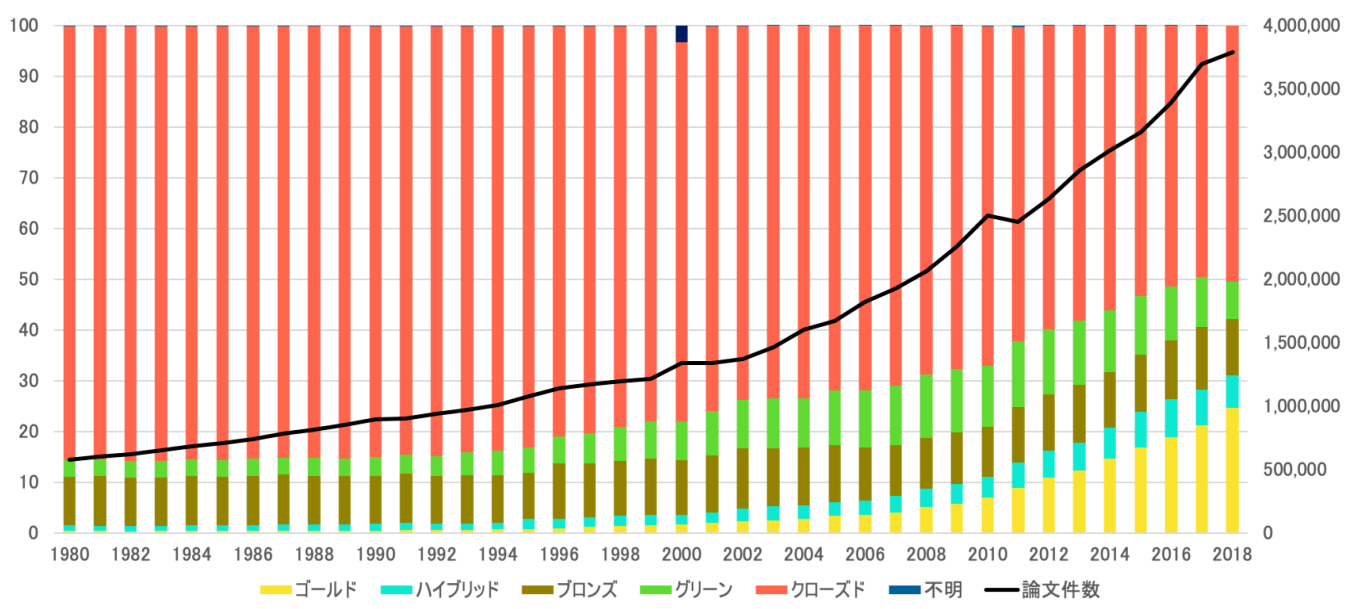

図 9: 世界における出版年ごとの $\mathrm{OA}$ 状況.

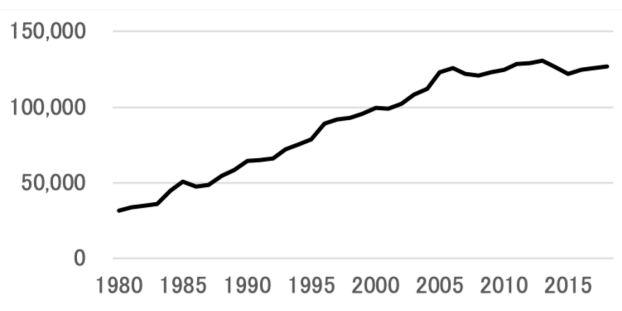

図 10: Scopus での日本の論文件数の推移.

きるリポジトリであり，論文も多く収録している [59, 60]. 6 位の Hyper Articles en Ligne (HAL) は フランス全土のリポジトリとして捉えられ，多くの 論文が登録されている. 8 位は永久識別子を提供す るハンドルシステムであり, 別にランディングペー
ジが存在すると考えられる．9位は DergiPark とい うトルコの学術雑誌のホスティングと編集管理シス テムを提供しているサービスであり，リポジトリで はなく出版者であると考えられる. 詳しくみたとこ ろ，これらの論文の oa_locationsには英語ページ とトルコ語ページが格納されており, 英語ページは host_type が publisher であるのに対して, トル コ語のものでは repository となっている. そのた め, リポジトリとして捉えるのは誤りであると思わ れる. 10 位は HathiTrust の電子図書館である.

なお表 5 と表 6 の論文件数にカウントされてい るものは, 出版者で OA となっているものも含まれ ており，全てが表 1 におけるグリーンではない.グ リーンに貢献しているリポジトリ（出版者では OA 


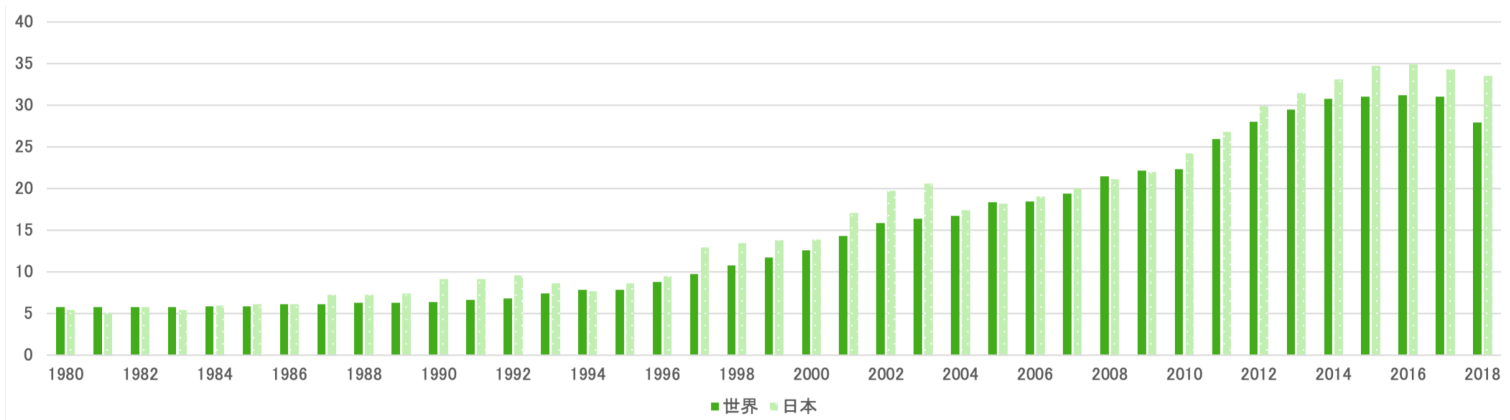

図 11: 出版年ごとのリポジトリによる OA 状況.

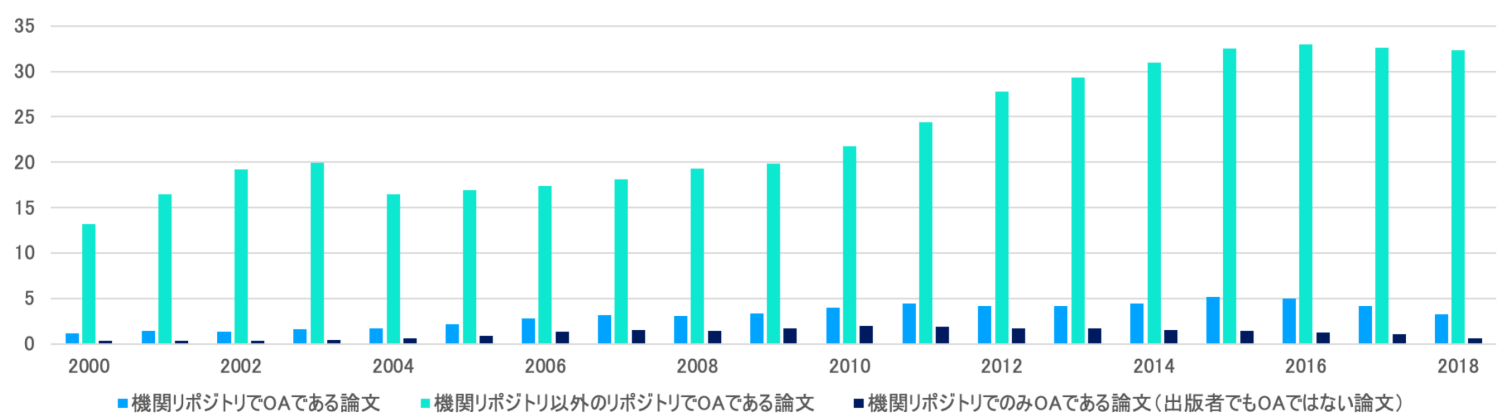

図 12: 日本における出版年ごとのリポジトリによる OA 状況.

でない論文を多く公開するリポジトリ）を調査した ところ，概ね表 5 と表 6 の順位に変動はなかった。

表 5: 日本の論文が公開されているリポジトリ上位 10 件.

\begin{tabular}{r|l|r}
\hline & リポジトリ & 論文件数 \\
\hline 1 & pdfs.semanticscholar.org & 272,902 \\
2 & www.ncbi.nlm.nih.gov & 154,672 \\
3 & europepmc.org & 115,888 \\
4 & arxiv.org & 28,875 \\
5 & repository.kulib.kyoto-u.ac.jp & 11,937 \\
6 & eprints.lib.hokudai.ac.jp & 9,322 \\
7 & figshare.com & 5,038 \\
8 & cds.cern.ch & 4,944 \\
9 & tsukuba.repo.nii.ac.jp & 4,494 \\
10 & kanazawa-u.repo.nii.ac.jp & 3,555 \\
\hline
\end{tabular}

\section{5 考察}

本章では，4章で得られた結果を考察する.

表 3 より, 日本の OA である論文の割合は $41.83 \%$ であり，世界における割合 $(29.77 \%)$ よりも高いこ とが判明した. 日本の論文の OA の割合の高さの理
表 6: 世界の論文が公開されているリポジトリ上位 10 件.

\begin{tabular}{r|l|r}
\hline & リポジトリ & 論文件数 \\
\hline 1 & pdfs.semanticscholar.org & $8,714,986$ \\
2 & www.ncbi.nlm.nih.gov & $4,549,458$ \\
3 & europepmc.org & $3,830,596$ \\
4 & arxiv.org & 895,370 \\
5 & zenodo.org & 339,266 \\
6 & hal.archives-ouvertes.fr & 285,491 \\
7 & cds.cern.ch & 162,320 \\
8 & hdl.handle.net & 124,104 \\
9 & dergipark.org.tr & 103,632 \\
10 & babel.hathitrust.org & 101,256 \\
\hline
\end{tabular}

由として, ブロンズの割合の高さが挙げられる.眓 8 より, 過去の論文によってブロンズの割合が高い ことが判明した．特にその割合が高い 1980〜2003 年に出版されたブロンズの 228,834 件の論文うち, 189,272 件 (82.71\%) がJ-STAGE で公開されてい ることがわかった. 1980〜2003 年に出版された出版 者で OA である論文（ゴールド，ハイブリッド，ブ ロンズのいずれかの $\mathrm{OA}$ 種別が付与される論文）は 251,838 件あるが，そのうち J-STAGE で公開され 
ているものは 194,321 件（77.16\%）であった.よっ て, 他の出版者と比較すると, J-STAGEにはライ センスが付与されていない過去の論文の割合が高 いといえる。これらの論文について，著者から学協 会に著作権が譲渡されている場合には CC-BY ライ センスを一括して遡及的に付与することも法的には 可能であるはずであるが, 実際には広範な再利用を 認めるライセンスを遡及的に, 著者の了承を得ず付 与することには大きな反発が起こることも予想され る. 個別の著者に了承を得る労力も大きいことを考 えると, 当面は遡及的なゴールドへの移行は困難で あろう。

日本と世界共通の近年の傾向として，ゴールドの 割合の上昇が挙げられる. 4.2 節では, 学際的領域で はメガジャーナルの影響でゴールドの割合が高くなっ ていることを報告した，全体のゴールドの割合の上 昇へのメガジャーナルの影響についても調査した. ここではメガジャーナルとして Scientific Reports と PLOS ONE を考慮する．2014～2018 年の各出 版年において日本における前年からのゴールドの 論文の増減率を計算したところ，それぞれ $28.68 \%$ ， $29.04 \%, 18.29 \%, 23.23 \%, 4.15 \%$ あった. 対して メガジャーナルの増減率はそれぞれ $2.50 \%, 21.99 \%$ ， $11.34 \%, 7.32 \%,-15.65 \%$ あった. よって, 日本の ゴールドの割合の上昇はメガジャーナルではなく, その他の OA ジャーナルによるものであるといえる.

リポジトリによる OA についての調査では, 機関 リポジトリで公開されている論文の割合は $2.36 \%$, 機関リポジトリのみで公開されている論文の割合 は $0.83 \%$ であった. 以前にも指摘されているとおり, 日本の機関リポジトリのグリーンへの貢献は小さい [48]. 大学の機関リポジトリでは，一定の人員を割 いて，機関リポジトリに登録されていない論文の著 者にその論文の提出を促すメールを送付していると ころもある ${ }^{[61]}$ 。学術情報空間全体における OA の 割合を増加させるためにも, $\mathrm{OA}$ 情報を参照して, どこでも OA になっていない論文から優先的に教員 に提出をお願いする，といった工夫が求められる. グリーン OA を認めているジャーナルに掲載されて おり，他の機関りポジトリで既に公開されている論

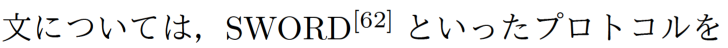
利用して機関リポジトリ間で論文の共有を行い，大 学の貢献を形作る新しいチャネルといった役割を果 たしていくといったことが考えられる.多くの日本 の論文を公開している Semantic Scholar, PubMed
Central といった外部のリポジトリとの連携も考え られるだろう。

このような工夫を可能にするには，各機関がそ れぞれの OA の現状を把握できることを可能にす ることが必要である. 国立大学図書館協会オープ ンアクセス委員会が 2016〜2017 年にかけて実施し た調査 ${ }^{[39]}$ では，全体の論文件数やゴールドの論文 件数を「不明」や概数で回答した大学図書館が約 半数であった．各機関が現状を認識して戦略を立 てやすくするためにも, ドイツにおける Open Ac-

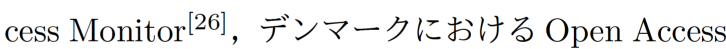
Indicator ${ }^{[63]}$ のような，現状の把握と評価を継続的 に可能にする仕組みやツールの開発が必要だろう.

Open Access Monitor は, 有償・無償のデータ ベースからドイッの各機関の論文のデータを継続 的に取得することによって構築されている. 持続可 能性の観点から, 可能な限り無償のデータベースの みで構築することが望ましい. Crossref や JaLC と いった DOI 登録機関が提供するメタデータで, 各著 者と ORCID といった研究者の識別子や著者の各所 属機関と ROR といった機関の識別子の紐付けが進 むと，APIを使用することで継続的に各機関の論文 を把握しやすくなる．さらに Crossref DOI が付与 されている論文については, Unpaywall の API を 使用することで $\mathrm{OA}$ 状況を把握することが可能とな る. 特に, Crossref と ORCID は連携していること から, 各機関が各研究者の ORCID を把握しており, 論文のメタデータでの ORCID の普及が進めば，各 機関の論文を把握することは可能になる。2020 年 3 月までに登録された Crossref のレコード全件 [64] を使用して調査したところ、2015 年以降に出版さ れた学術雑誌論文 19,007,035 件では, 著者として延 ベ 79,935,641 名がメタデータに記録されているが, そのうち ORCID と紐づけられている著者は延べ 5,874,678 名（7.35\%）であった.このことから，現 時点では実現は難しいと思われる. 論文のメタデー タにおいて ORCID や ROR といった識別子の普及 が進むことが求められる.

本稿では, Unpaywall のデータベースのスナップ ショットを使用して調査を実施したが，全てのリポ ジトリが対象となっているわけではなく, 日本の 機関リポジトリは対象となっていないものも多い (3.2.1 項参照) 。IRDB で「本文あり」「資源タイ プが journal-article」「言語が英語」という 3 つ の条件を満たす論文を検索したところ，106,519 件 
がヒットした（2020 年 2 月 26 日時点）。これらの 条件を満たす論文全件に Crossref DOI が付与され ていることを想定すると，機関リポジトリで OA で ある論文の割合は $5.32 \%$ であといえる。これらの 論文全件が Scopus の收録対象となっているわけで はないので実際の数値はわずかに小さいと考えられ るが，本稿の調査での機関リポジトリで OA である 論文の割合 $2.36 \%$ （表 4 参照）と比較すると, 2.25 倍の差異が存在することになる。このように実際の 数值との乘離が懸念されるが，1 章で述べたとおり， Unpaywall は多くの研究者に使用されているプラグ インである.よって機関リポジトリで $\mathrm{OA}$ となって いる論文の発見可能性という観点から, Unpaywall を使用したこの調査には一定の意義があると考える. 将来には, より正確なグリーンの状況を探るために も，IRDBを使用した調查に取り組みたい。

\section{6 おわりに}

本稿は, Unpaywall のデータベースのスナップ ショットを利用して, 日本における OA 状況の調査 を実施した。 日本の OA である論文の割合は $41.83 \%$ であり，世界における割合（29.77\%）よりも高いこ とが判明した.この割合の高さの要因として, 過去に 出版された論文の多くがブロンズであることが挙げ られる. 日本と世界共通して, 近年はゴールドの割合 が上昇している. 日本で論文の公開のために頻繁に 使用されている機関リポジトリ以外のリポジトリと しては, arXiv, figshare, CERN Document Server であることが判明した。本稿の調査では, 機関リポ ジトリに登録されている論文の割合は, 近年は一定 して $5 \%$ 程度であるとの結果が出たが, Unpaywall に把握されていない機関リポジトリも存在するため, IRDB を使用した調査も必要になってくる.

本稿では日本全体の結果のみを示したが, 各機関 が OA に関する取り組みの評価や戦略を策定するに は，各機関ごとに OA 状況を継続的に把握する必要 がある. 欧州での取り組み $[26,63]$ 等を参考にしつ つ，仕組みづくりが必要になってくるだろう。

\section{謝辞}

本研究は JSPS 科研費 18K13235，20K20132，稲 盛研究助成, JST AIP JPMJCR19U1 の助成を受
けたものである. また本研究は，オープンアクセス リポジトリ推進協会 (JPCOAR) コンテンツ流通 促進作業部会でのプロジェクトの一つとして進めら れた。

\section{参考文献}

[1] 佐藤翔: “オープンアクセスの広がりと現在の 争点”, 情報管理, Vol. 56, No. 7, pp. 414-424, 2013.

[2] "Read the Budapest Open Access Initiative", https://www. budapestopenaccessinitiative.org/read, 2002, 最終閲覧日: 2020 年 2 月 26 日.

[3] 佐藤翔: “学術情報流通と図書館 : オープンア クセスからオープンサイエンスヘ”, 四書館界, Vol. 70, No. 1, pp. 245-264, 2018.

[4] 時実象一: “オープンアクセス: 機関リポジト リの最近の動向”, 情報の科学と技術, Vol. 59, No. 5, pp. 231-237, 2009.

[5] 時実象一: “オープンアクセスの動向 (1) : オー プンアクセスの義務化とその影響”, 情報の科 学と技術, Vol. 64, No. 10, pp. 426-434, 2014.

[6] 国立大学図書館協会: “オープンアクセスに 関する声明”, https://www.mext.go.jp/b_ menu/shingi/gijyutu/gijyutu4/toushin/ attach/1283016.htm，2009，最終閲覧日： 2020 年 3 月 6 日.

[7] 内閣府: “第 4 期科学技術基本計画（平成 23 27 年度)”, https ://www8.cao.go.jp/cstp/ kihonkeikaku/index4.html, 2011, 最終閲覧 日: 2020 年 3 月 6 日.

[8] 国際的動向を踏まえたオープンサイエン スに関する検討会：“我が国におけるオー プンサイエンス推進のあり方について〜サ イエンスの新たな飛躍の時代の幕開け〜”, https://www8.cao.go.jp/cstp/sonota/ openscience/150330_openscience_1.pdf, 2015, 最終閲覽日: 2020 年 3 月 6 日. 
[9] 森いづみ: “CA1753 - 動向レビュー : 大学キャ ンパスの中のオープンアクセス”, カレントア ウェアネス, , No. 309, pp. 14-17, 2011.

[10] 京都大学図書館機構: “京都大学オープンア クセス方針”, https://www.kulib.kyoto-u. ac.jp/content0/13092, 最終閲覧日: 2020 年 3 月 7 日.

[11] Piwowar, Heather; Priem, Jason; Larivière, Vincent; Alperin, Juan Pablo; Matthias, Lisa; Norlander, Bree; Farley, Ashley; West, Jevin; Haustein, Stefanie: "The state of OA: a largescale analysis of the prevalence and impact of Open Access articles", PeerJ, Vol. 6, p. e4375, 2018.

[12] Martín-Martín, Alberto; Costas, Rodrigo; van Leeuwen, Thed; López-Cózar, Emilio Delgado: "Evidence of open access of scientific publications in google scholar: A large-scale analysis", Journal of Informetrics, Vol. 12, No. 3, pp. 819-841, 2018.

[13] Piwowar, Heather; Priem, Jason; Orr, Richard: "The future of OA: A large-scale analysis projecting Open Access publication and readership", bioRxiv, 2019.

[14] Unpaywall: "Browser extension", https:// unpaywall.org/products/extension, 最終 閲覧日：2020 年 3 月 5 日.

[15] Harnad, Stevan; Brody, Tim; Vallières, François; Carr, Les; Hitchcock, Steve; Gingras, Yves; Oppenheim, Charles; Stamerjohanns, Heinrich; Hilf, Eberhard R: "The access/impact problem and the green and gold roads to Open Access", Serials review, Vol. 30, No. 4, pp. 310-314, 2004.

[16] Harnad, Stevan; Brody, Tim; Vallières, François; Carr, Les; Hitchcock, Steve; Gingras, Yves; Oppenheim, Charles; Hajjem, Chawki; Hilf, Eberhard R: "The access/impact problem and the green and gold roads to Open Access: An update", Serials review, Vol. 34, No. 1, pp. 36-40, 2008.
[17] Suber, Peter: "Gratis and libre open access", SPARC Open Access Newsletter, 2008.

[18] Laakso, Mikael; Björk, Bo-Christer: "Delayed open access: An overlooked high-impact category of openly available scientific literature", Journal of the American Society for Information Science and Technology, Vol. 64, No. 7, pp. 1323-1329, 2013.

[19] "ResearchGate", https: //www . researchgate.net/，最終閲覧日: 2020 年 2 月 14 日.

[20] "Academia", https://www.academia.edu/, 最終閲覧日：2020 年 2 月 14 日.

[21] Björk, Bo-Christer: "Gold, green, and black open access.", Learned publishing, Vol. 30, No. 2, pp. 173-175, 2017.

[22] Archambault, Éric; Amyot, Didier; Deschamps, Philippe; Nicol, Aurore; Provencher, Françoise; Rebout, Lise; Roberge, Guillaume: "Proportion of open access papers published in peer-reviewed journals at the European and world levels 1996-2013", RTD-B6-PP-2011-2: Study to develop a set of indicators to measure open access, 2014.

[23] Corrall, Sheila: "The open movement: What libraries can do.", In Proceedings of the Charleston Library Conference, pp. 559-570, Purdue University Press, 2015.

[24] Haschak, Paul G: "The 'platinum route' to open access: a case study of E-JASL: The Electronic journal of academic and special librarianship", Information Research, Vol. 12, No. 4, 2007.

[25] Watson, Roger: "Gold, green, or diamond: Which is best?", Nurse Author \& Editor, Vol. 28, No. 2, p. 6, 2018.

[26] Forschungszentrum Jülich: "Open Access Monitor", https://open-access-monitor. de, 最終閲覧日 : 2020 年 2 月 18 日. 
[27] 尾鷲瑞穂; 野崎久美子; 張替香織; 村上章人: “ 国立環境研究所におけるオープンアクセス実態 調査”, 情報の科学と技術, Vol. 68, No. 10, pp. 500-505, 2018.

[28] Jamali, Hamid R: "Copyright compliance and infringement in ResearchGate full-text journal articles", Scientometrics, Vol. 112, No. 1, pp. 241-254, 2017.

[29] Fortney, Katie; Gonder, Justin: "A social networking site is not an open access repository", https://osc. universityof california. edu/2015/12/a-social-networking-siteis-not-an-open-access-repository/, 2015, 最終閲覧日：2020 年 2 月 14 日.

[30] Björk, Bo-Christer: "The open access movement at a crossroad: Are the big publishers and academic social media taking over?", Learned Publishing, Vol. 29, No. 2, pp. 131134, 2016.

[31] Shamash, Katie: "Article processing charges (APCs) and subscriptions", https: //www.jisc.ac.uk/reports/apcsand-subscriptions, 2002, 最終閲覧日：2020 年 3 月 5 日.

[32] "Directory of Open Access Journals (DOAJ)"，https://doaj.org/，最終閲 覧日：2019 年 11 月 29 日.

[33] Beall, Jeffrey: "Predatory publishers are corrupting open access", Nature, Vol. 489, No. 7415, p. 179, 2012.

[34] 千葉浩之: “CA1960 - ハゲタカジャーナル問 題 : 大学図書館員の視点から”, カレントアウェ アネス, , No. 341, pp. 12-14, 2019.

[35] Lynch, Clifford A: "Institutional repositories: Essential infrastructure for scholarship in the digital age", portal: Libraries and the Academy, Vol. 3, No. 2, pp. 327-336, 2003.

[36] “機関リポジトリ：デジタル時代における 学術研究に不可欠のインフラストラクチ ヤ", https://www.nii.ac.jp/irp/archive/ translation/arl/, 最終閲覧日 : 2020 年 2 月 20 日.

[37] 福澤尚美: “ジャーナルに注目した主要国の論 文発表の特徵 : オープンアクセス、出版国、使 用言語の分析”, In 研究・イノベーション学会 年次学術大会講演要旨集, pp. 624-627, 研究· イノベーション学会, 2016.

[38] 池内有為; 林和弘; 赤池伸一: “研究データ 公開と論文のオープンアクセスに関する実態 調査”, NISTEP RESEARCH MATERIAL, , No. 268, pp. 1-108, 2017.

[39] 国立大学四書館協会オープンアクセス委員会: “ 「オープンアクセスへの取り組み状況に関する実 態調査」報告書", https://www.janul.jp/j/ projects/oa/OA_report_201703.pdf, 2017, 最終閲覧日：2020 年 2 月 26 日.

[40] 小陳左和子; 矢野恵子: “ジャーナル購読から オープンアクセス出版への転換に向けて”, 大 学図書館研究, Vol. 109, p. 2015, 2018.

[41] 尾城孝一; 市古みどり: “オープンアクセスの 現在地とその先にあるもの”, 大学図書館研究, Vol. 109, p. 2014, 2018.

[42] "Affiliation Retrieval API", https: //dev.elsevier.com/documentation/ AffiliationRetrievalAPI.wadl, 2019, 最 終閲覧日 : 2019 年 12 月 29 日.

[43] "Journal List", http://help.incites. clarivate.com/incitesLiveESI/ ESIGroup/overviewESI/esi JournalsList. html, 2019, 最終閲覧日：2019 年 12 月 18 日.

[44] Schuldt, Karsten: "On Open Access Analytics in Europe", https://sonar.ch/post/ open-access-analytics-europe/, 2019, 最 終閲覧日：2020 年 2 月 18 日.

[45] Priem, Jason: "What do the types of oa_status (green, gold, hybrid, and bronze) mean?", https://support.unpaywall. org/support/solutions/articles/ 44001777288-what-do-the-types-ofoa-status-green-gold-hybrid-and- 
bronze-mean-, 2019, 最終閲覧日 : 2020 年 2 月 18 日.

[46] Priem, Jason: "How do we decide if a given journal is fully OA?", https: //support. unpaywall.org/support/ solutions/articles/44001792752-howdo-we-decide-if-a-given-journal-isfully-oa-, 2019, 最終閲覧日: 2020 年 2 月 18 日.

[47] “学術機関リポジトリデータベース (IRDB) ”, https://irdb.nii.ac.jp/, 最終閲覧日:2020 年 2 月 26 日.

[48] 国公私立大学図書館協力委員会シンポジウム 企画・運営委員会: “平成 28 年度大学図書館 シンポジウム「10 年後の大学図書館を考える : オープンアクセス時代の大学図書館の新たな役 割」報告”, 大学図書館研究, Vol. 110, p. 2025, 2018.

[49] Chan, Leslie: "Reimagining the role of institutional repositories in open scholarship", $\quad$ https://www.coarrepositories.org/files/2_OpenAIRECOAR_keynotes_LeslieChan.pdf，最終閲覧 日: 2020 年 2 月 20 日.

[50] "OA Location object", https://unpaywall. org/data-format\#oa-location-object, 最 終閲覧日 : 2020 年 2 月 18 日.

[51] Python Software Foundation: "urllib.parse", https://docs.python.org/ja/ 3/library/urllib.parse.html\#moduleurllib.parse，最終閲覧日：2020 年 2 月 18 日.

[52] Directory of Open Access Journals (DOAJ): "Guide to applying", https://doaj.org/ apply/guide/, 最終閲覧日 : 2020 年 2 月 18 日.

[53] Elsevier: "Content Policy and Selection", https://www.elsevier.com/solutions/ scopus/how-scopus-works/content/ content-policy-and-selection, 最終閲覧 日: 2020 年 2 月 25 日.
[54] 佐藤翔: “オープンアクセスメガジャーナルの 興隆，と，停滞”，情報の科学と技術, Vol. 68, No. 4, pp. 187-188, 2018.

[55] 白木澤佳子; 水野充: “JST リンクセンター”, 情報管理, Vol. 45, No. 7, pp. 502-505, 2002.

[56] 独立行政法人科学技術振興機構: “J-STAGE 500 誌へのあゆみ”, J-STAGE NEWS, Vol. 特 別号, p. 3, 2008.

[57] National Institutes of Health (NIH): "PubMed Central Submission Assistance", https://www.nihlibrary.nih. gov/services/editing/pubmed-centralsubmission-assistance, 最終閲覧日：2020 年 2 月 25 日.

[58] Europe PMC plus: "User guide", https:// plus . europepmc.org/user-guide, 最終閲覧 日: 2020 年 2 月 25 日.

[59] Sicilia, Miguel-Angel; García-Barriocanal, Elena; Sánchez-Alonso, Salvador: "Community curation in open dataset repositories: Insights from Zenodo", Procedia Computer Science, Vol. 106, pp. 54-60, 2017.

[60] Peters, Isabella; Kraker, Peter; Lex, Elisabeth; Gumpenberger, Christian; Gorraiz, Juan Ignacio: "Zenodo in the spotlight of traditional and new metrics", Frontiers in Research Metrics and Analytics, Vol. 2, p. 13, 2017.

[61] 河合将志; 林正治; 尾城孝一; 新妻聡; 西澤正己; 山地一禎: “グリーンオープンアクセス進捗度 に関する計量分析”, 情報知識学会誌, Vol. 28, No. 4, pp. 298-301, 2018.

[62] "SWORD", http://swordapp.org/, 最終閲 覧日：2020 年 11 月 28 日.

[63] Ministry of Higher Education and Science: "Danish Open Access Indicator", https:// www.oaindikator.dk/en，最終閲覧日：2020 年 3 月 9 日.

[64] "March 2020 Public Data File from Crossref", http://dx.doi.org/10.13003/83b2gp，最 終閲覧日：2020年 11 月 28 日.

(2020年 5 月15日 受付)

（2021年 1月19日 採択）

(2020年 3月25日 プレプリント公開) http://hdl. handle. net/2433/246424 